PROFESSIONAL PAPER

\title{
Effect of postharvest UV-C irradiation as physical elicitor on anti-nutritional factor, B-vitamins and mineral profile of Clerodendrum volubile leaves
}

\author{
Adetuyi F.O. *, Karigidi, K.O., Akintimehinm E.S., Fajembola T.F. \\ Biochemistry Unit, Chemical Sciences Department, Ondo State University of Science and Technology, PMB 353, \\ Okitipupa, Ondo State, Nigeria
}

*Corresponding author: adetuyifoluso5@gmail.com

\begin{abstract}
The effect of postharvest UV-C irradiation on the antinutrients (phytate, saponin, tannin), B-vitamins, and mineral profile of Clerodendrum volubile leaves was evaluated. The leaves were cleaned, detached, divided into two parts, one part was irradiated with UV-C lamp at wavelength $210 \mathrm{~nm}$, average dose of $2.217 \mathrm{~J} / \mathrm{m}^{2}$ for 20 minutes while the other was left untreated, the two were stored for 24 hours at room temperature. The phytate, saponin, tannin, B vitamins and mineral content of the leaves were analysed after irradiation and storage using standard methods. Mineral and molar ratios were calculated. UV-C irradiation substantially decreased the phytate contents from $18.12 \mathrm{to} 9.02 \mathrm{mg} / \mathrm{g}$ but increased the tannin contents from 0.68 to $1.42 \mathrm{~g} / 100 \mathrm{~g}$ and saponin contents from 1.44 to $1.52 \mathrm{~g} / 100 \mathrm{~g}$. The phytate and saponin contents reduced in storage but the tannin content increased. The B vitamins reduced after UV-C irradiation and further in storage with the exception of pyridoxine $\left(\mathrm{B}_{6}\right)$ which increased significantly. The minerals $\mathrm{P}, \mathrm{Mn}, \mathrm{Na}, \mathrm{Ca}$ and $\mathrm{Mg}$ content increased while $\mathrm{K}$ decreased with UV-C irradiation and no effect on the Fe content of white butterfly $\mathrm{C}$. volubile leaves. After UV - C irradiation the mineral ratios $\mathrm{Ca}: \mathrm{P}, \mathrm{Na}: \mathrm{K}, \mathrm{Ca}: \mathrm{Mg}, \mathrm{Ca}: \mathrm{K}$ and the miliequivalent ratio $\mathrm{K}:(\mathrm{Ca}+\mathrm{Mg})$ were still within the required standard for their availability for absorption. $[\mathrm{Ca}][\mathrm{Phytate}] /[\mathrm{Zn}]$ molar ratios $(0.0003-0.0006$ $\mathrm{mol} / \mathrm{kg}$ ) were below $0.5 \mathrm{~mol} / \mathrm{kg}$ the critical value. Irradiating food just like other food processing methods will depend on what the food has to contribute to the total diet.
\end{abstract}

Keywords: $C$ volubile, antinutrient, B vitamin, mineral, UV-C irradiation, mineral ratio

\section{Introduction}

Leafy vegetables play crucial role in reducing the effect of food insecurity in many parts of the world. They contribute to a great extent to the intake of proteins, minerals, vitamins, fibre and health-supportive phytochemicals such as flavonoids, saponins, terpenoids, and lignans. This has made vegetables an important factor in the diet of man (Solanke and Awonorin, 2002, Oomah and Mazza, 2000). The nutritional and health-promoting benefits of vegetables tend to decrease over time as a result of the perishable nature of vegetables (Olaiya et al., 2016).

Clerodendrum voluble White butterfly is a member of the family Verbenaceae, a climbing shrub, commonly grown in deciduous forests across Africa (Burkill 1985). It is known as'Eweta', 'Dagba' or 'Marugbojiyatan' in Ikale, Apoi and Ilaje land of Ondo State, also known as 'Obnettete' in Itsekiri and Urhobo land of Niger-Delta, Nigeria (Erukainure et al., 2010). It is used in the management of arthritis, rheumatism, dropsy, swellings, oedema, and gout also as an anti-abortifacient and sedative (Burkill 1985). A lot has been done on C. volubile, the nutritional and phytochemical qualities, in-vitro antioxidant activity have been reported (Erukainure et al., 2011, Ogunwa et al., 2016). The evaluation has been carried out and reported on the phytochemicals, antioxidant, anti-inflammatory and antihyperlipidemic potentials of $C$. volubile (Adetuyi et al., 2018) Adefegha and Oboh, 2016 in their study of $C$. volubile leaf extract reported the inhibitory properties of the leaf extract on enzymes related to non-insulin dependent diabetes mellitus and hypertension. Microbial spoilage has always been the bane of fresh fruits and vegetable. It can be prevented by surface treatments which has to be gentle so as to keep the integrity and the freshness of fruits and vegetables. The processing techniques of ultraviolet $\mathrm{C}$ (UV-C) light treatment has proved to be effective as the gentle surface treatment to reduce microbial loads of pathogens on fresh fruits and vegetables (Turtoi 2013). UV-light irradiation treatment holds considerable promise for shelf-life extension of fresh fruits and vegetables (Ribeiro et al., 2012). The non-ionized UV-light irradiation is simple, economical and more reliable in comparison with other ionized irradiation ( $\mathrm{Lu}$ et al., 1991). UV-C at low doses has beneficial effect on vegetables in a phenomenon known as hormesis. UV-C irradiation can induce specific secondary metabolites biosynthesis in fresh fruits with concomitant antioxidant properties. Postharvest UV-C treatment induced accumulation of phytoalexins as a defense mechanism which in turn triggers the accumulation of phytochemicals like the total phenolics, carotenoids 
and vitamin $\mathrm{C}$ thereby causing the improvement in the nutritional status of the fruits (Cisneros-Zevallos 2003, Alothman et al., 2009). UV-C irradiation as reported by Pongprasert et al., (2011) caused delay in deterioration processes, ripening and senescence of tropical fruits. Treatment of fresh fruits and vegetables with ultraviolet (UV-C) radiation has been described by Olaiya et al, (2016) as a new approach for the enhancement of antioxidant activity of vegetables.

It has been previously reported by Adetuyi et al., (2018), that postharvest UV-C radiation of $C$ volubile leaves for $20 \mathrm{mins}$ had consistently increased the antioxidant capacity of $C$ volubile leaves extracts and that UV-C treatments may be a useful non-chemical way for the enhancement of the antioxidant post-harvest quality of the vegetable (Adetuyi et al., 2018). Since micronutrient and some vitamins are influenced by irradiation (Harder et al., 2016). The aim of this study is to evaluate the effect of postharvest UV-C irradiation on minerals, antinutrients, B vitamins and mineral bioavailability of $C$ volubile leaves in the process of enhancing the antioxidant post-harvest quality of $C$ volubile vegetable through postharvest UV-C treatment.

\section{Materials and methods}

\section{Sample collection}

Fresh leaves of $C$ volubile were harvested from a farm in Okitipupa, Ondo State, Nigeria, identified and authenticated at the herbarium of Biological Sciences Department, OSUSTECH. Edible portion of the leaves were separated, rinsed to remove dirt. Samples were divided into two groups: group 1 was treated with UV-C irradiation for $20 \mathrm{~min}$ and group 2 was without irradiation as control.

\section{Radiation Treatment}

The UV-C lamps were stabilized on for 15 min before treatment. Samples were placed on a rectangular polypropylene tray in the radiation chamber. Radiation was done under controlled condition at room temperature with UV radiation dose of $2.217 \mathrm{~J} / \mathrm{m}^{2}$ on the average and wavelength of UV-C lamp of $210 \mathrm{~nm}$ as described previously by Adetuyi et al., (2018).

\section{Storage Method}

The treated and untreated samples were stored for $24 \mathrm{~h}$ at controlled condition stimulating Nigeria local market storage condition for vegetables. They were placed inside a plastic basin; sprinkled with water, at $6 \mathrm{pm}$, placed inside polypropylene bag and left outside at room temperature of $27 \pm 1{ }^{\circ} \mathrm{C}$ (Adetuyi and Ogundahunsi, 2010).

\section{Sample preparation}

The average serving size $50 \mathrm{~g}$ of the treated as well as untreated stored samples (50 g) were separated, washed, completely drained, chopped, air dried and analysed for minerals, antinutrients, B vitamins and mineral bioavailability. All analysis was carried out in triplicate.

\section{Phytate determination}

Spectrophotometric method for phytic acid determination from Vaintraub and Lapteva (1988) was adopted. The $0.5 \mathrm{~g}$ of both prepared sam- ples were taken, $10 \mathrm{~mL}$ of $0.2 \mathrm{~N} \mathrm{HCl}$ added and left to stand for 1 hour at room temperature, it was centrifuged at $3000 \times \mathrm{g}$ for $30 \mathrm{mins}$. The clear supernatant $(3 \mathrm{~mL})$ and wade reagent $(2 \mathrm{~mL})$ were added together, homogenized and centrifuged at $3000 \times \mathrm{g}$ for $10 \mathrm{~min}$. Absorbance was measured at $500 \mathrm{~nm}$ with a UV spectrophotometer (JENWAY 6305, Barloworld Scientific Ltd., Dunmow, Essex, UK). Phytate amount was calculated from determined phytic acid.

\section{Saponin determination}

The spectrophotometric method of Brunner (1994) was used for Saponin determination. $2 \mathrm{~g}$ of the ground sample was taken into $100 \mathrm{ml}$ of Isobutyl alcohol and mixed using laboratory shaker for $5 \mathrm{~h}$. The mixture was filtered into $20 \mathrm{ml}$ of $40 \%$ saturated solution of $\mathrm{MgCO}_{3}$ and filtered again with Whatman No 1 filter paper to get a clean colourless solution. Then $1 \mathrm{ml}$ of the colourless solution and $2 \mathrm{ml}$ of $5 \% \mathrm{FeCl}_{3}$ solution were added together in a $50 \mathrm{ml}$ volumetric flask, made up to the mark with distilled water, allowed to stand for $30 \mathrm{~min}$ for colour development. Absorbance measured against the blank at $380 \mathrm{~nm}$.

\section{Tannin determination}

The method of Makkar and Goodchild (1996) was adopted for tannin determination. $250 \mathrm{mg}$ of the sample from which pigments and fat have been removed with diethyl ether containing $1 \%$ acetic acid, was taken into $10 \mathrm{~mL}$ of $70 \%$ aqueous acetone for extraction for $2 \mathrm{~h}$ at $30^{\circ} \mathrm{C}$ using water-bath. The total polyphenols (expressed as tannin) was determined using Folin ciocalteau reagent and $2.5 \mathrm{~mL} \mathrm{Na}_{2} \mathrm{CO}_{3}$ solution. Absorbance was measured at $725 \mathrm{~nm}$.

\section{Minerals determination}

The official method of AOAC (2005) was used for the mineral $\mathrm{Zn}$, $\mathrm{Fe}, \mathrm{Mn}, \mathrm{Ca}$ and $\mathrm{Mg}$ determination. The minerals were determined on aliquots of the solutions of the ash by established atomic absorption spectrophotometry method using atomic absorption spectrophotometer (model 372) (Perkin Elmer, 1982). The Na and K contents were determined by Flame photometry with $\mathrm{NaCl}$ and $\mathrm{KCl}$ as standards, Vanado-molybdate method for P. The mineral ratio of $\mathrm{Ca}: \mathrm{P}, \mathrm{Na}: \mathrm{K}, \mathrm{Ca}: \mathrm{Mg}$, $\mathrm{Ca}: \mathrm{K}, \mathrm{Fe}: \mathrm{Zn}$ and the milliequivalent ratio of $[\mathrm{K}:(\mathrm{Ca}+\mathrm{Mg})]$ of the samples were calculated according to Adeyeye et al., (2012).

\section{Molar ratio of antinutrients to minerals determination}

The method of Norhaizan and Nor Faizadatul Ain (2009) was used for the calculation of the molar ratios of the phytate to $\mathrm{Ca}, \mathrm{Zn}$ and $\mathrm{Fe}$. The method of Ferguson et al. (1988) was used for the calculation of Phy : $\mathrm{Zn}, \mathrm{Ca}:$ Phy and $[\mathrm{Ca}][\mathrm{phy}] /[\mathrm{Zn}]$ molar ratios $[$ Phytate $=660, \mathrm{Fe}=56$, $\mathrm{Zn}=65.40, \mathrm{Ca}=40]$.

\section{Vitamins determination}

The method of Harold et al., (1987) was used for Pyridoxine (Vitamin $\mathrm{B}_{6}$ ) determination while AOAC (2005) spectrophotometric method was adopted for the determination of Thiamine (Vitamin $\mathrm{B}_{1}$ ) and Riboflavin (Vitamin $\mathrm{B}_{2}$ ).

For Pyridoxine (Vitamin $\mathrm{B}_{6}$ ): Two gram $(2 \mathrm{~g})$ of the sample, $5 \mathrm{ml}$ of 2 $\mathrm{N}$ acetic acid, $5 \mathrm{ml}$ of dichloroethane and $90 \mathrm{ml}$ of distilled water were taken into $250 \mathrm{ml}$ flask, placed in water bath for $20 \mathrm{~min}$, cooled, and centrifuged; the first $10 \mathrm{ml}$ of the aliquot was discarded. Standards were 
prepared. The absorbance of the standards and the samples were read at $575 \mathrm{~nm}$.

For Thiamine (Vitamin $\mathrm{B}_{1}$ ): $0.5 \mathrm{~g}$ of the sample, $30 \mathrm{ml}$ dichloroethane, $30 \mathrm{ml} \mathrm{HCl} \mathrm{(1:1)} \mathrm{and} 50 \mathrm{ml} \mathrm{NH} \mathrm{OH}_{4}$ solution were added together. It was filtered with Whatman no1 filter paper. The absorbance was read at $415 \mathrm{~nm}$.

For Riboflavin (Vitamin $\mathrm{B}_{2}$ ): $1 \mathrm{~g}$ of the sample, $50 \mathrm{ml}$ of $50 \%$ methanol and $50 \mathrm{ml}$ of $17 \% \mathrm{NaCO}_{3}$ were added. It was filtered with Whatman no1 filter paper. The absorbance was read at $415 \mathrm{~nm}$.

\section{Result and discussion}

\section{Antinutrient Content}

UV-C irradiation significantly decreased the phytate content of the vegetable, but increased the tannin and saponin contents of the vegetable (Table 1). Phytate content decreased by approximately $50 \%$, while saponin and tannin contents increased by approximately $109 \%$ and $6 \%$, respectively. The decrease in phytate could be attributed to the action of free radicals generated during irradiation which ultimately resulted to low inositol and inositol phosphates in the vegetable (De Boland, et al., 1975). Furthermore, the reduction may also be due to cleavage in the structure of the phytic acid itself by the irradiation (Duodu, et al., 1999). Bhat et al. (2007), also reported reduction in the phytate content of irradiated leafy vegetables. Antinutrients adversely affect the bioavailability and utilization of nutrients, which may result in neurological disorders and sometimes death (Olagunju et al., 2018). Our findings that $\mathrm{UV}-\mathrm{C}$ irradiation caused an increase in the tannin content of the vegetable is in agreement with the report of Bhat et al., (2007) and Mohammed (2009) where tannin content of Mucuna seeds and $\mathrm{Cu}-$ lantro plant increased after irradiation but was opposite to the report of Abu-Tarboush, (1998) and Villavicencio, et al., (2000), where decrease in the tannin content of plant seeds and Brazilian seeds were observed after irradiation. The increase in tannin might be because the irradiation

\section{Statistical analysis}

Obtained results were expressed as mean. Analysis of variance (ANOVA) and Duncan's multiple range test for mean separations were according to Statistical Analysis System proprietary software (SAS, 2002). Significance accepted at $\mathrm{P}<0.05$. induced oxidative stress in the vegetable and de novo synthesis of tannins by increasing the activity of phenylalanine ammonia lyase (PAL) an enzyme for the biosynthesis of tannins (Mohammed 2009). Increase in saponin content as a result of irradiation has been observed by other researcher who worked on effect of irradiation on plants (Vardhan and Shukla 2017, Elhaak et al., 2018). The enzyme squalene synthase (SS) and squalene epoxidase (SE) are the enzymes that catalyses the initial steps in the pathway of various triterpenoids biosynthesis. SS catalysed the biosynthesis of squalene from farnesyl diphosphate and SE the synthesis of oxidosqualene from squalene (Vardhan and Shukla 2017). The increase in the saponin content could be due to the increase in the coding genes for SS and SE in response to irradiation and consequently enhanced saponin content (Vardhan and Shukla 2017). In storage the antinutrients phytate and tannin reduced significantly in both irradiated and non-irradiated samples. This result is in agreement with the report of Adetuyi et al., 2008a that the phytate and tannin content of okra reduced in storage. The reduction in phytate and tannin in storage could be attributed to the action of phytase and polyphenol oxidase enzymes respectively.

Table 1: Antinutrient content of UV-C irradiated and stored $C$ volubile leaves

\begin{tabular}{lllll}
\hline Antinutrients & Un-irradiated & Irradiated & $\begin{array}{l}\text { Stored } \\
\text { Un-irradiated }\end{array}$ & Stored irradiated \\
\hline Phytate $\mathrm{mg} / \mathrm{g}$ & $18.12 \mathrm{a}$ & $9.02 \mathrm{~b}$ & $6.59 \mathrm{c}$ & $7.30 \mathrm{c}$ \\
Saponin $\mathrm{g} / 100 \mathrm{~g}$ & $0.68 \mathrm{c}$ & $1.42 \mathrm{a}$ & $0.35 \mathrm{~d}$ & $1.00 \mathrm{~b}$ \\
Tannin $\mathrm{g} / 100 \mathrm{~g}$ & $1.44 \mathrm{c}$ & $1.52 \mathrm{~b}$ & $1.55 \mathrm{~b}$ & $1.69 \mathrm{a}$ \\
\hline
\end{tabular}

Values $=$ mean triplicate readings.

Values with the same letter on the same row are not significantly $(P<0.05)$ different.

\section{Vitamin-B contents}

The B vitamins Thiamine $\left(\mathrm{B}_{1}\right)$, Riboflavin $\left(\mathrm{B}_{2}\right)$ and Pyridoxine $\left(\mathrm{B}_{6}\right)$ content UV-C irradiation treated and stored $\mathrm{C}$ volubile leaves are presented in Table 2. Fresh $C$ volubile leaves had significantly $(p<0.05)$ higher vitamin $B_{6}(192.70 \mathrm{mg} / 100 \mathrm{~g})$ than vitamin $\mathrm{B}_{2}(72.16 \mathrm{mg} / 100 \mathrm{~g})$ and vitamin $\mathrm{B}_{1}$ $(48.82 \mathrm{mg} / 100 \mathrm{~g})$. UV-C irradiation of the leaves resulted in slight reduction in vitamin $\mathrm{B}_{6}(1.3 \%)$, while vitamins $\mathrm{B}_{1}$ and $\mathrm{B}_{2}$ reduced by approximately $6 \%$. Previous researchers reported similar reduction in B vitamins of two varieties of Brazilian beans after irradiation (Villavicencio, et al., 2000). The losses in B vitamins as result of irradiation are minimal in comparison to other processes of conservation of foods and the studies relating to the effects of radiation on the B vitamin content of foods are still inconclusive (Harder, et al., 2016, Lima et al., 2018). Storage of the leaves (irradiated and un-irradiated) resulted in significant reduction in vitamins $\mathrm{B}_{1}$ and $\mathrm{B}_{2}$, but pyridoxine $\left(\mathrm{B}_{6}\right)$ increased. Un-irradiated sample content increased from $192.70 \mathrm{mg} / 100 \mathrm{~g}$ to $237.88 \mathrm{mg} / 100 \mathrm{~g}$ while the irradiated sample increased from $190.22 \mathrm{mg} / 100 \mathrm{~g}$ to $249.22 \mathrm{mg} / 100 \mathrm{~g}$. 
Penas et al (2013) reported that vitamins are gradually lost during storage at the practical conditions in food shops. To the best of our knowledge, this study presents the first data on B vitamins thiamin, riboflavin and pyridoxine levels in $\mathrm{UV}-\mathrm{C}$ irradiated $C$. volubile leaves.

Table 2: Vitamin B content of UV-C irradiated and stored C. volubile leaves in $\mathrm{mg} / \mathrm{g}$

\begin{tabular}{lllll}
\hline Vitamins & Un-irradiated & \multicolumn{1}{c}{ Irradiated } & Stored Un-irradiated & Stored irradiated \\
\hline Thiamine $\left(\right.$ Vit. $\left.\mathrm{B}_{1}\right)$ & $48.82 \mathrm{a}$ & $45.69 \mathrm{~b}$ & $41.33 \mathrm{~d}$ & $43.15 \mathrm{c}$ \\
Riboflavin $\left(\right.$ Vit. $\left.\mathrm{B}_{2}\right)$ & $72.16 \mathrm{a}$ & $68.12 \mathrm{~b}$ & $67.33 \mathrm{~b}$ & $66.42 \mathrm{c}$ \\
Pyridoxine $\left(\right.$ Vit. $\left.\mathrm{B}_{6}\right)$ & $192.70 \mathrm{c}$ & $190.22 \mathrm{~d}$ & $237.88 \mathrm{~b}$ & $249.22 \mathrm{a}$ \\
\hline
\end{tabular}

Values = mean triplicate readings.

Values with the same letter on the same row are not significantly $(P<0.05)$ different.

\section{Mineral content}

The mineral contents of irradiated and un-irradiated $C$. volubile leaves are presented in Table 3. Potassium $(\mathrm{K})$, magnesium $(\mathrm{Mg})$, sodium $(\mathrm{Na})$ and calcium $(\mathrm{Ca})$ were the most abundant elements in irradiated and un-irradiated $C$. volubile leaves. There was no significant change in the observed mineral content of the vegetable after UV-C irradiation with the exception of $\mathrm{Mg}$ which increased significantly from $8.11 \mathrm{mg} / \mathrm{g}$ to $9.85 \mathrm{mg} / \mathrm{g}$ and $\mathrm{K}$ which decreased significantly from $16.23 \mathrm{mg} / \mathrm{g}$ to $13.97 \mathrm{mg} / \mathrm{g}$. There are no comprehensive studies on the mineral content changes as a result of UV-C irradiation, but Olaiya et al., (2016) reported that there were no significant changes in the micronutrients content in cucumber and tomato after UV-C irradiation. As a result of the storage, $\mathrm{P}$ and $\mathrm{Ca}$ content increased significantly while the content of other observed minerals decreased significantly. The reason for the increase in $\mathrm{P}$ and $\mathrm{Ca}$ remains unclear. However, the decrease in other minerals in storage could be due to the physiological and metabolic activities going on within the cell of the vegetable (Adetuyi et al., 2008b)

Table 3: Mineral content of UV-C irradiated and stored C. volubile leaves in $\mathrm{mg} / \mathrm{g}$

\begin{tabular}{lllll}
\hline Minerals & Un-irradiated & Irradiated & Stored Un-irradiated & Stored Irradiated \\
\hline $\mathrm{P}$ & $0.79 \mathrm{~d}$ & $0.98 \mathrm{c}$ & $1.28 \mathrm{~b}$ & $1.53 \mathrm{a}$ \\
$\mathrm{Zn}$ & $0.11 \mathrm{a}$ & $0.12 \mathrm{a}$ & $0.06 \mathrm{~b}$ & $0.07 \mathrm{~b}$ \\
$\mathrm{Fe}$ & $0.20 \mathrm{a}$ & $0.20 \mathrm{a}$ & $0.18 \mathrm{a}$ & $0.19 \mathrm{a}$ \\
$\mathrm{Mn}$ & $0.30 \mathrm{a}$ & $0.32 \mathrm{a}$ & $0.28 \mathrm{a}$ & $0.30 \mathrm{a}$ \\
$\mathrm{K}$ & $16.23 \mathrm{a}$ & $13.97 \mathrm{~b}$ & $11.01 \mathrm{~d}$ & $12.43 \mathrm{c}$ \\
$\mathrm{Na}$ & $1.83 \mathrm{~b}$ & $2.07 \mathrm{a}$ & $1.69 \mathrm{c}$ & $1.89 \mathrm{~b}$ \\
$\mathrm{Ca}$ & $1.59 \mathrm{~d}$ & $1.78 \mathrm{~b}$ & $1.66 \mathrm{c}$ & $2.11 \mathrm{a}$ \\
$\mathrm{mg}$ & $8.11 \mathrm{~b}$ & $9.85 \mathrm{a}$ & $3.95 \mathrm{~d}$ & $5.48 \mathrm{c}$ \\
\hline
\end{tabular}

Values $=$ mean triplicate readings.

Values with the same letter on the same row are not significantly $(P<0.05)$ different.

\section{Mineral ratio}

The absorption of minerals in the body is determined by the interactions of minerals present in the mineral source (Soetan et al., 2010), therefore the mineral ratios reveals more than the mineral composition of the foods. When $\mathrm{Ca}$ : P ratio in food is high, $\mathrm{Ca}$ absorption in the intestine is favored for bones formation, contrary to that foods that are high in protein and P may cause Ca loss in urine (Adeyeye et al., 2012, Adeoti et al., 2013). The $\mathrm{Ca}$ : P ratio of samples $C$. volubile leaves in all observed conditions were greater than 1 (Table 4). The $\mathrm{Ca}$ : $\mathrm{P}$ ratio of the studied vegetable $C$. volubile could promote $\mathrm{Ca}$ absorption with the purpose of the formation of bones and teeth since foods with $\mathrm{Ca}: \mathrm{P}$ ratio greater than 1 are good source of $\mathrm{Ca}$ and with less than 0.5 are considered poor (Alinnor and Oze, 2011). The $\mathrm{Na}: \mathrm{K}$ ratio of all the samples were less than 1. This is considered good for hypertensive patients since a good food should have $\mathrm{Na}$ : K ratio of less than one (Jacob et al., 2015). Vegetables with this kind of ratio when consumed will caused a reduction in the blood pressure of hypertensive patients because low $\mathrm{Na}$ and high 
$\mathrm{K}$ in food intake, will help to reduce high blood pressure in hypertensive patients (Perez and Chang, 2014). When Ca : Mg ratio is high, $\mathrm{Mg}$ absorption efficiency reduces, movement of $\mathrm{Mg}$ into bone reduced and the activity of demineralizing parathyroid hormone increases (Mai et al., 2003). The $\mathrm{Ca}: \mathrm{Mg}$ ratio reported in this study was less than 2. Mai et al., (2003) reported the $\mathrm{Ca}: \mathrm{Mg}$ ratio of 2 as the recommended ratio for the balance absorption of $\mathrm{Mg} / \mathrm{Ca}$. The $\mathrm{Ca}: \mathrm{Mg}$ ratio in this study will enhance increase in $\mathrm{Mg}$ absorption, increase in movement of $\mathrm{Mg}$ into bones and reduction in the activity of demineralizing parathyroid hormone since the $\mathrm{Ca}: \mathrm{Mg}$ ratio was less than 2. The $\mathrm{Ca}: \mathrm{K}$ ratio reported in this study was less than 4 . A good source of Ca should have $\mathrm{Ca}: \mathrm{K}$ ratio of $4: 1$ (Watts 2010). The calcium/potassium ratio is indicative of thyroid function. High Calcium over Potassium $(>10)$ indicates a decreased thyroid effect at the cellular level. A low $\mathrm{Ca} / \mathrm{K}$ ratio $(<3)$ indicates an excess thyroid effect at the cellular level. The $\mathrm{Ca}$ $: \mathrm{K}$ ratio is considered the thyroid ratio since $\mathrm{Ca}$ and $\mathrm{K}$ are important in regulating the thyroid activity (Olagbemide et al., 2016). Zn and Fe are the most abundant trace minerals in human body, they are assessed together, have the same dietary sources, their absorption is affected by the same factors and their deficiency occurs simultaneously (Lim et al., 2013). The $\mathrm{Fe}: \mathrm{Zn}$ ratio of irradiated and un-irradiated vegetable were less than 2 but the $\mathrm{Fe}: \mathrm{Zn}$ ratio of the stored samples were greater than 2. From the result of the irradiated and un-irradiated samples, the $\mathrm{Zn}$ absorption will be impaired but in the stored sample the $\mathrm{Zn}$ absorption will not be impaired because Fe will not impair the absorption of $\mathrm{Zn}$ when $\mathrm{Fe}: \mathrm{Zn}$ is greater than 2. According to Pérès et al. (2001) iron did not impair zinc absorption at $\mathrm{Fe}: \mathrm{Zn}$ ratio of 2:1. Milliequivalent ratios $\mathrm{K}:(\mathrm{Ca}+\mathrm{Mg})$ of the stored irradiated and un-irradiated samples were higher than 2.2 but the UV-C irradiated sample has a value of 1.96 which was less than 2.2. This shows that the irradiated vegetable will discourage hypomagnesaemia in man (Adeyeye et al., 2012) since the consumption of the irradiated vegetable this will ensure the availability of more $\mathrm{Mg}$ in the body.

Table 4: Mineral ratio in UV-C irradiated and stored C. volubile leaves

\begin{tabular}{lllll}
\hline Mineral ratio & Un-irradiated & Irradiated & Stored Un-irradiated & Stored irradiated \\
\hline $\mathrm{Ca}: \mathrm{P}$ & $2.01 \mathrm{a}$ & $1.82 \mathrm{~b}$ & $1.30 \mathrm{c}$ & $1.38 \mathrm{c}$ \\
$\mathrm{Na}: \mathrm{K}$ & $0.11 \mathrm{~b}$ & $0.15 \mathrm{a}$ & $0.15 \mathrm{a}$ & $0.15 \mathrm{a}$ \\
$\mathrm{Ca}: \mathrm{Mg}$ & $0.20 \mathrm{~b}$ & $0.18 \mathrm{~b}$ & $0.42 \mathrm{a}$ & $0.39 \mathrm{a}$ \\
$\mathrm{Ca}: \mathrm{K}$ & $0.10 \mathrm{c}$ & $0.13 \mathrm{c}$ & $0.15 \mathrm{~b}$ & $0.17 \mathrm{a}$ \\
$\mathrm{Fe}: \mathrm{Zn}$ & $1.82 \mathrm{c}$ & $1.67 \mathrm{c}$ & $3.00 \mathrm{a}$ & $2.71 \mathrm{~b}$ \\
{$[\mathrm{~K}:(\mathrm{Ca}+\mathrm{Mg})]^{\mathrm{X}}$} & $2.75 \mathrm{~b}$ & $1.96 \mathrm{c}$ & $3.42 \mathrm{a}$ & $2.83 \mathrm{~b}$ \\
\hline
\end{tabular}

$x$ - miliequivalent

Values = mean triplicate readings.

Values with the same letter on the same row are not significantly $(P<0.05)$ different.

\section{Molar ratio}

The molar ratios of $C$. volubile irradiated and un-irradiated leaves are shown in Table 5. The phytate : Fe ratio ranged from 3.30 for stored un-irradiated vegetable to 7.00 un-irradiated vegetable. Iron absorption will not be inhibited by phytate when phytate : Fe ratios are less than 1.0 (Hurrell et al., 2003). The values of phytate : Fe ratios in this study were all greater than 1, indicating poor Fe availability for absorption in the irradiated, un-irradiated and stored vegetables. The phytate : $\mathrm{Zn}$ molar ratio of the irradiated, un-irradiated and stored vegetable were less than 15 with the irradiated vegetable having the least value of 7.0. The phytate content in the irradiated, un-irradiated and stored vegetable will not prevent $\mathrm{Zn}$ availability for absorption because the phytate $: \mathrm{Zn}$ molar ratios were below the critical value of 15 (Ferguson et al., 1988). The Ca : phytate molar ratio in this study ranged from 1.39 un-irradiated vegetable to 4.82 stored irradiated vegetable, these values were less than 6.0 indicating incomplete phytate precipitation. The determinant in the solubility of phytate and bound $\mathrm{Zn}$ is the dietary calcium $(\mathrm{Ca})$, phytate precipitation is incomplete when dietary $\mathrm{Ca}$ : phytate molar ratios are less than 6.0. (Adetuyi et al., 2011). There is a better index for predicting $\mathrm{Zn}$ availability for absorption, this is the calculated [Ca] [Phytate] / [Zn] molar ratio because of the interaction of Ca to phytate (Adetuyi et al., 2011). There will be Ca interference with $\mathrm{Zn}$ availability for absorption when [Ca][Phy] / [Zn] molar ratio is greater than 0.5 $\mathrm{mol} / \mathrm{kg}$ (Davies and Warrington, 1986). The $[\mathrm{Ca}][$ Phytate $] /[\mathrm{Zn}]$ molar ratio for the irradiated, un-irradiated and stored vegetable ranged from $0.0003 \mathrm{~mol} / \mathrm{Kg}$ irradiated vegetable to $0.0006 \mathrm{~mol} / \mathrm{kg}$ stored irradiated vegetable, these values were below $0.5 \mathrm{~mol} / \mathrm{kg}$, indicating that dietary $\mathrm{Zn}$ are available for absorption in the vegetable. 
Table 5: Molar ratio of UV-C irradiated and stored C. volubile leaves

\begin{tabular}{lllll}
\hline Molar ratio & Un-irradiated & Irradiated & Stored Un-irradiated & Stored irradiated \\
\hline $\mathrm{Phy}: \mathrm{Fe}$ & $7.00 \mathrm{a}$ & $3.50 \mathrm{~b}$ & $3.30 \mathrm{c}$ & $3.67 \mathrm{~b}$ \\
$\mathrm{Phy}: \mathrm{Zn}$ & $14.00 \mathrm{a}$ & $7.00 \mathrm{c}$ & $10.00 \mathrm{~b}$ & $11.00 \mathrm{~b}$ \\
$\mathrm{Ca}: \mathrm{Phy}$ & $1.39 \mathrm{~d}$ & $3.21 \mathrm{c}$ & $4.20 \mathrm{~b}$ & $4.82 \mathrm{a}$ \\
{$[\mathrm{Ca}][\mathrm{Phy}] /[\mathrm{Zn}]^{\mathrm{x}}$} & $0.0005 \mathrm{~b}$ & $0.0003 \mathrm{c}$ & $0.0004 \mathrm{c}$ & $0.0006 \mathrm{a}$ \\
\hline
\end{tabular}

X $-\mathrm{mol} / \mathrm{Kg}$

Values $=$ mean triplicate readings.

Values with the same letter on the same row are not significantly $(P<0.05)$ different Phy - phytate.

\section{Conclusions}

The results of this study, showed clearly that UV-C irradiation reduced significantly the content of phytates, but increased the content of saponin and tannin which possessed antinutritional and antioxidant activity in $C$. volubile leaves. The result also showed that UV-C irradiation caused reduction in the $\mathrm{B}$ vitamins, increase in the minerals $\mathrm{P}, \mathrm{Zn}, \mathrm{Mn}, \mathrm{Na}, \mathrm{Ca}$ and $\mathrm{Mg}$ but decrease in $\mathrm{K}$ and has no effect on the Fe content of C. volubile leaves. The mineral ratios and the milliequivalent ratios $\mathrm{K}:(\mathrm{Ca}+\mathrm{Mg})$ as affected by UV-C irradiation were within the required standard for their availability for absorption. The $[\mathrm{Ca}][\mathrm{Phytate}] /[\mathrm{Zn}]$ molar ratio for the UV-C irradiated, un-irradiated and stored $C$. volubile vegetable were below $0.5 \mathrm{~mol} / \mathrm{kg}$. This therefore suggest that irradiating food just like other food processing methods will depend on what the food has to contribute to the total diet since UV-C irradiation caused reduction in the observed B vitamins but increase in some observed minerals.

\section{References}

Abu-Tarboush, H. M. (1998) Irradiation inactivation of some antinutritional factors in plant seeds. Journal of Agricultural and Food Chemistry, $462698-2702$.

Adefegha, S. A., Oboh, G. (2016) Antioxidant and inhibitory properties of Clerodendrum volubile leaf extracts on key enzymes relevant to non-insulin dependent diabetes mellitus and hypertension. Journal of Taibah University of Science, 10 521-533.

Adeoti, O. A., Elutilo, O. O., Babalola, J. O., Jimoh, K. O., Azeez, L. A., Rafiu, K. A. (2013) Proximate, Mineral. Amino Acid and Fatty Acid Compositions of Maize Tuwo-Cirina Forda Flour Blends. Greener Journal of Biological Sciences, 3(4) 165-171.

Adetuyi, F.O., Osagie, A.U., Adekunle, A.T (2011) Nutrient, antinutrient, mineral and zinc bioavailability of okra Abelmoschus esculentus (L) Moench Variety. American Journal of Food and Nutrition, 1(2) 49-54 doi:10.5251/ajfn.2011.1.2.49.54.

Adetuyi, F.O., Ogundahunsi, G.A (2010) Antioxidant properties of Telfairia occidentalis as affected by the market storage method in Nigeria. Pakistan Journal of Science and Industrial Research, 53 (2) 76-80.

Adetuyi, F.O., Osagie, A.U., Adekunle, A.T (2008a) Effect of postharvest storage techniques on the nutritional properties of Benin indigenous okra Abelmoschus esculentus (L) Moench. Pakistan Journal of Nutrition, 7 (5) 652-657.

Adetuyi, F.O., Ayileye, T.A., Dada, I.B.O (2008b) Comparative study of quality changes in Shea butter coated pawpaw Carica papaya fruit during storage. Pakistan Journal of Nutrition, 7 (5) 658-662.

Adetuyi,F.O., Karigidi, K.O., Akintimehin, E.S (2018) Effect of postharvest UV-C treatments on the bioactive components, antioxidant and inhibitory properties of clerodendrum volubile leaves. Journal of the Saudi Society of Agricultural Sciences, https://doi.org/10.1016/j.jssas.2018.03.005

Adeyeye, E.I., Orisakeye, O.T., Oyarekua, M.A (2012) Composition, mineral safety index, calcium, zinc and phytate interrelationships in four fast-foods consumed in Nigeria. Bulleting of Chemical Society of Ethiopia 26(1) 43-54. DOI: http://dx.doi.org/10.4314/bcse.v26i1.5

Alinnor, I.J., Oze, R. (2011) Chemical evaluation of the nutritive value of Pentaclethra macrophylla benth (African Oil Bean) Seeds. Pakistan Journal of Nutrition, 10(4) 355-359.

Alothman, M., Bhat, R., Karim, A.A. (2009) UV radiation-induced changes of antioxidant capacity of fresh-cut tropical fruits. Innovative Food Science Emergence Technology, 10 512-516

AOAC (2005) Association of official analytical chemists, official methods of analysis (18 ${ }^{\text {th }}$ ed.). Washington, DC: AOAC International.

Bhat, R., Sridhar, K. R., and Tomita-Yokotani, K. (2007) Effect of ionizing radiation on antinutritional features of velvet bean seeds (Mucuna pruriens). Food Chemistry, 103 860-866

Brunner, J.H. (1984) Direct spectrophotometric determination of saponin. Analytical Chemistry, 341314 -1326. 
Burkill H.M. (1985) The useful plants of tropical West Africa. 1, Royal Botanic Gardens, Kew. 319.

Cisneros-Zevallos, L. (2003) The use of controlled postharvest abiotic stresses as a tool for enhancing the nutraceutical content and adding-value of fresh fruits and vegetables. Journal of Food Science, 68(5) 1560-1565.

Davies, N.T., Warrington, S (1986) The phytic acid, mineral, trace element, protein and moisture content of UK Asian immigrant foods. Human Nutrition-Applied Nutrition 40A 49-59.

De Boland, A. R., Garner, G. B., O’Bell, B. L. (1975) Identification and properties of 'phytate' in cereal grains and oil seed products. Journal of Agricultural and Food Chemistry, 23 1186-1189.

Duodu, K. G., Minnaar, A., Taylor, J. R. N. (1999) Effect of cooking and irradiation on the labile vitamin and antinutrients content of a traditional African sorghum porridge and spinach relish. Food Chemistry, 66 21-27.

Elhaak, M.A., Masoud, M., Zayed, M.A., Gad, D (2018) Effect of gamma irradiation on some active constituents and metabolites of Cichorium pumilum Jacq. Egypt Journal of Experimental Biology, (Bot.), 14(1) 153 - 159 DOI: 10.5455/egyjebb.20180428085058

Erukainure, O.L. Oke, O.V., Ajiboye, A.J., Okafor, O.Y. (2011) Nutritional qualities and phytochemical constituents of Clerodendrum volubile, a tropical non-conventional vegetable. International Food Research Journal, 18 (4) 1393-1399.

Erukainure, O.L., Oke, O.V., Owolabi, F.O., Adenekan, S.O. (2010) Antioxidant nutrient properties and antioxidant activities of obenetete (Clerodendrum volubile), a non-conventional leafy vegetable consumed in Nigeria. Africa Journal of Food Agriculture Nutrition and Development, 10(10) 4156 - 4167

Ferguson, E.L, Gibson R.S, Lilian, T.U, Berry N., Ounpuu, S (1988) Phytate, zinc and calcium content of 30 East Africa foods and their calculated phytate : Zn, Ca : phytate and [Ca] [phytate]/ [Zn] molar ratios. Journal of Food Composition and Analysis. $1316-325$.

Harder, M.N.C., Arthur, V., Arthur, P.B (2016) Irradiation of foods: Processing technology and effects on nutrients: Effect of ionizing radiation on food components. Encyclopedia of Food and Health 476 - 481. http://dx.doi.org/10.1016/B978-0-12-384947-2.00405-0

Harold, E., Ronald, S.K., Ronald, S., (1987) Pearson's Chemical Analysis of Foods, eight ed. Longman House, Burnt, M., Harlow, Essex CM 202 JE, England.

Hurrell, R. F., Juillerat, M. A., Reddy, M. B., Lynch, S. R., Dassenko, S. A., Cook, J. D. (2003) Soy protein, phytate, and iron absorption in humans. The American journal of clinical nutrition, 56(3) 573-578.

Jacob, A. G., Etong, D. I., Tijjani, A. (2015) Proximate, Mineral and Antinutritional Compositions of Melon (Citrullus lanatus) Seeds. British Journal of Research, 2(5) 142-151.

Lim, K.H.C., Riddell, L.J., Nowson,C.A., Booth, A.O and Szymlek-Gay, E.A (2013) Iron and zinc nutrition in the economically-developed world: A review. Nutrients. 5 3184-3211; doi:10.3390/nu5083184

Lima, F., Vieira, K., Santos, M., Mendes de Souza, P (2018) Effects of radiation technologies on food nutritional quality. Descriptive Food Science, Chapter 7, 137 - 152 http://dx.doi.org/10.5772/intechopen.80437

Lu, J. Y., Stevens, C., Khan, V. A., Kabwe, M. K., Wilson, C. L. (1991) The effect of ultraviolet irradiation on shelf-life and ripening of peaches and apples. Journal of Food Quality, 14 299-305.

Makkar, A.O.S., Goodchild, V.A. (1996) Quantification of tannin: A laboratory manual. International centre for Agricultural Research in the Dry area (ICARDA). Allepo, Syria iv, 25.

Mai, T.T., Hung, N.K., Kawakami, M., Kawase, M., Chuyen, N. (2003) Micronutrient status of primary school girls in rural and urban areas of South Vietnam. Asia Pacific Journal of Clinical Nutrition, 12 (2) 178-185.

Mohammed, A.A (2009) Effect of low dose gamma irradiation on some phytochemicals and scavenger ability of in vitro Culantro (Eryngium foetidum) plantlets. Medicinal and Aromatic Plant Science and Biotechnology $332-36$.

Norhaizan, M.E., Nor Faizadatul Ain A.W (2009) Determination of phytate, iron, zinc, calcium contents and their molar ratios in commonly consumed raw and prepared food in Malaysia. Malaysia Journal of Nutrition 15(2) 213 - 222.

Ogunwa T. H., Ajiboye S. A., Sholanke D. R., Awe O. B., Ademoye T. A., Oloye O. B., Ilesanmi O. C. (2015) Nutritional Evaluation of Clerodendrum volubile (Marugbo) Leaves. Asian Journal of Plant Science and Research, 5(11) 26-31

Olagunju, O.F., Ezekiel, O.O., Ogunshe, A.O., Oyeyinka, S.A., Ijabadeniyi, O.A. (2018). Effects of fermentation on proximate composition, mineral profile and antinutrients of tamarind (Tamarindus indica L.) seed in the production of daddawa-type condiment. LWT - Food Science and Technology 90 455-459. https://doi.org/10.1016/j.lwt.2017.12.064

Olaiya, C.O., Karigidi, K.O., Ogunleye, A.B., Rukayat O. K. (2016) Possible Enhancement of Nutrients and Antioxidant Capacity of Two Tropical Fruits by UV Radiation Treatment. Advance in Life Science and Technology, 46 80-85

Olagbemide, P. T., Ojiezeh, T. I., Adarabioyo, M. I. (2016) Essential vitamins and mineral salts in some extracts used in alternative medicine in Nigeria. Der Pharma Chemica, 8 (14) 10-18. 
Oomah, B.D., Mazza, G. (2000) Functional Foods. In: Francis, F.J. (Ed.), The Wiley Encyclopedia of Science and Technology, Vol. 2, 2nd ed. Wiley, New York, NY. pp. 1176-1182.

Peñas E, Sidro B, Ullate M, Vidal-Valverde C, Frias J. (2013) Impact of storage under ambient conditions on the vitamin content of dehydrated vegetables. Food Science and Technology International, 19(2) 133-41. doi: 10.1177/1082013212442188.

Perkin-Elmer, (1982) Analytical Methods for Atomic Absorption Spectrophotometry. Perkin-Elmer Corp., USA.

Perez, V., Chang, E. T. (2014) Sodium-to-potassium ratio and blood pressure, hypertension, and related factors. Advances in Nutrition: An International Review Journal, 5(6) 712-741.

Pérès, J., Bureau, F., Neuville, D., Arhan, P., Bouglé, D (2001) Inhibition of zinc absorption by iron depends on their ratio. Journal of Trace Elements in Medicine and Biology 15(4) 237-241 DOI: 10.1016/S0946-672X (01)80039-0

Pongprasert, N. Sekozawa, Y. Sugaya, S. Gemma, H. (2011) The role and mode of action of UV-C hormesis in reducing cellular oxidative stress and the consequential chilling injury of banana fruit peel. International Food Research Journal 18(2) 741-749

Ribeiro, C., João, C., Bartolommeo, A. (2012) Prospects of UV radiation for application in postharvest technology. Emirate Journal of Food and Agriculture, 24 (6) 586-597.

SAS (2002) Statistical Analysis System Proprietary software. Release 8.3. SAS Institute Inc., Carry, NC

Soetan, K. O., Olaiya, C. O., Oyewole, O. E. (2010) The importance of mineral elements for humans, domestic animals and plants-A review. African Journal of Food Science, 4(5) 200-222.

Solanke, O., Awonorin, S. O. (2002) Kinetics of vitamin C degradation in some tropical green leafy vegetables during blanching. Nigerian Food Journal, 20 24-32.

Turtoi, M (2013) Ultraviolet light treatment of fresh fruitsand vegetables surface: A review. Journal of Agroalimentary Processes and Technologies, 19(3) 325-337.

Vaintraub, I.A., Lapteva, N.A (1988) "Colorimetric determination of phytate in unpurified extracts of seeds and the products of their processing," Analytical Biochemistry. 175 (1) 227-230.

Vardhan, P.V., Shukla, L.I (2017) Gamma irradiation of medicinally important plants and the enhancement of secondary metabolite production. International Journal of Radiation Biology, DOI: 10.1080/09553002.2017.1344788

Villavicencio, A.L.C.H., Mancini-Filho, J., Henry Delincee, H., Greiner, R (2000) Effect of irradiation on anti-nutrients (total phenolics, tannins and phytate) in Brazilian beans. Radiation Physics and Chemistry 57289 - 293

Watts, D. L. (2010) HTMA Mineral Ratios. A brief discussion of their clinical importance. Trace Elem Newsletter, 21 1-3. 